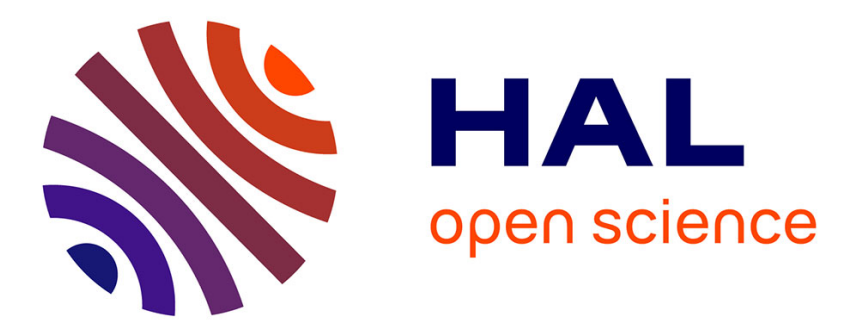

\title{
Carbon Cycling and Organic Radiocarbon Reservoir Effect in a Meromictic Crater Lake (Lac Pavin, Puy-de-Dôme, France)
}

Patrick Albéric, Didier Jézéquel, L. Bergonzini, Emmanuel Chapron, Eric Viollier, Marc Massault, Gil Michard

\section{To cite this version:}

Patrick Albéric, Didier Jézéquel, L. Bergonzini, Emmanuel Chapron, Eric Viollier, et al.. Carbon Cycling and Organic Radiocarbon Reservoir Effect in a Meromictic Crater Lake (Lac Pavin, Puy-deDôme, France). Radiocarbon, 2013, 55 (2-4), pp.1029-1042. insu-00834245

\section{HAL Id: insu-00834245}

\section{https://hal-insu.archives-ouvertes.fr/insu-00834245}

Submitted on 4 Sep 2013

HAL is a multi-disciplinary open access archive for the deposit and dissemination of scientific research documents, whether they are published or not. The documents may come from teaching and research institutions in France or abroad, or from public or private research centers.
L'archive ouverte pluridisciplinaire HAL, est destinée au dépôt et à la diffusion de documents scientifiques de niveau recherche, publiés ou non, émanant des établissements d'enseignement et de recherche français ou étrangers, des laboratoires publics ou privés. 


\title{
CARBON CYCLING AND ORGANIC RADIOCARBON RESERVOIR EFFECT IN A MEROMICTIC CRATER LAKE (LAC PAVIN, PUY-DE-DÔME, FRANCE)
}

\author{
Patrick Albéric ${ }^{1,2} \cdot$ Didier Jézéquel $^{3} \cdot$ Laurent Bergonzini $^{4} \cdot$ Emmanuel Chapron $^{1} \bullet$ Eric Viollier $^{3} \bullet$ \\ Marc Massault ${ }^{4}$ Gil Michard ${ }^{3}$
}

\begin{abstract}
Lac Pavin is a meromictic maar lake for which the interpretation of sediment radiocarbon dates is complicated by the existence of a largely undefined reservoir effect resulting from degradation of carbon stored in the bottom layer of the water column. A data set of the contemporary ${ }^{14} \mathrm{C}$ distribution of dissolved and particulate organic pools in the water column is presented to address this issue. Dissolved inorganic carbon (DIC) and organic carbon (DOC), plankton, suspended particulate organic carbon ( $\mathrm{POC}_{\text {susp }}$ ), sinking POC ( $\mathrm{POC}_{\text {sink }}$ ), and bottom sediment organic carbon ( $\left.\mathrm{SOC}\right)$ were analyzed. Presentday $\Delta^{14} \mathrm{C}$ values of DIC were measured ranging from $-750 \%$ in the monimolimnion to atmospheric values in lake surface waters and in spring inlet waters. A range of $\Delta^{14} \mathrm{C}$ values between -200 and $-300 \%$ was observed for superficial $\mathrm{POC}_{\text {susp}}$, $\mathrm{POC}_{\text {sink }}$, SOC, and DOC. This relatively uniform ${ }^{14} \mathrm{C}$ offset of the exported organic production from the surface waters to the bottom represents a contemporary reservoir effect of $\sim 2500$ yr. Laminated buried sediment samples and terrestrial vegetal macro-remains were used to evaluate temporal reservoir effect variations since the formation of the crater lake (7 ka cal BP). Buried sediment layers presented a similar offset or showed larger differences between $\Delta^{14} \mathrm{C}$ values of bulk sediment and terrestrial plant remains $(-400$ to $-500 \%$ ). Furthermore, an almost 0 -yr reservoir effect was inferred from the sediment layers deposited just above the volcanic bedrock at the early flooding of the crater, and increasing slightly within the first centuries of the lake's history. A second objective was to tentatively model a defined scenario of the cycling of carbon in the lake capable of predicting a modern reservoir effect. Alternative scenarios were then tested for which a larger contribution of deeper DIC would provide a model compatible with larger past reservoir effects. It is concluded that using $\Delta^{14} \mathrm{C}$ SOC variation in laminated lake sediments as a proxy of paleolimnological conditions may be valuable provided that more data on the dynamics of the ${ }^{14} \mathrm{C}$ composition of plankton and more detailed sampling of laminated sediment layers are available.
\end{abstract}

\section{INTRODUCTION}

Carbon inputs and cycling in freshwater contexts are known to greatly complicate interpretation of the radiocarbon dating of sediments and biological remains given that they present significant age offsets when compared with atmospheric values (Geyh et al. 1998; Ascough et al. 2010; Fernandes et al. 2012; Keaveney and Reimer 2012). Large temporal variations in this so-called reservoir effect in lakes have been previously addressed, mostly for carbonate fractions of sediments, and linked principally with variations in the water level (Geyh et al. 1998). Discrepancies between the ${ }^{14} \mathrm{C}$ ages of aquatic and aerial organic matter preserved in sedimentary archives as well as varve chronologies have previously been used to study long-term changes in fossil carbon fluxes and recycling processes in the water column of lakes (Pazdur et al. 1995). Recent contributions to the understanding of biogeochemical cycles (Mayorga et al. 2005; McNichol and Aluwihare 2007) have led to more integrated attempts in the description of reservoir effect ranges and variations in time, which are better addressed by studying complete lake ecosystem carbon pools (Keaveney et al. 2012; Zigah et al. 2012a; Fernandes et al., these proceedings). The 2 main goals of this work were (1) to describe and discuss variation in the ${ }^{14} \mathrm{C}$ content of different carbon pools in the water column of a meromictic crater lake for which modeling of the chemical functioning has been recently improved (Lopes et al. 2011; Jézéquel et al. 2012b); and (2) to evaluate the modeling of the ${ }^{14} \mathrm{C}$ content of particulate

\footnotetext{
${ }^{1}$ ISTO (Institut des Sciences de la Terre d'Orléans), Université d'Orléans CNRS UMR 7327, 1A rue de la férollerie, 45071 Orléans Cedex 2, France.

${ }^{2}$ Corresponding author. Email: patrick.alberic@univ-orleans.fr.

${ }^{3}$ LGE (Laboratoire de Géochimie des Eaux), Université Paris-Diderot \& IPGP CNRS UMR 7154, 75205 Paris Cedex 13, France.

${ }^{4}$ IDES (Interactions et Dynamique des Environnements de Surface), Université d’Orsay-Paris Sud CNRS UMR 8148, Bâtiment 504 rue du Belvédère, 91405 Orsay Cedex, France.
} 


\section{$P$ Albéric et al.}

organic sinking fluxes compared to modern conditions and then apply it to the prediction of past reservoir effects.

\section{MATERIALS AND METHODS}

\section{Overview of Lac Pavin Limnology}

Lac Pavin is a volcanic crater lake (92 m depth, $750 \mathrm{~m}$ diameter) about 7000 yr old (Juvigné 1992) that has been extensively studied in many aspects (see respectively for hydrobiology, geochemistry, physical structure, and paleoclimatology: Carrias et al. 1998; Michard et al. 1994; Aeschbach-Hertig et al. 2002; Schettler et al. 2007). A detailed modeling attempt of biogeochemical processes in Lac Pavin has been developed by Lopes et al. (2011) using the AquaSim ${ }^{\circledR}$ software (Reichert 1994, 1998) and applied to determine major methane oxidation pathways in the water column.

The 2 main factors controlling geochemical and microbiological processes in the deep-water column are a permanent anoxic bottom layer between 60 to $92 \mathrm{~m}$ depth (referred to as the monimolimnion) and underwater springs stepped inflows. Examples of components and mechanisms studied in this context are trace metals and dissolved organic carbon (DOC) behavior (Viollier et al. 1995; Albéric et al. 2000), dissolved inorganic carbon (DIC) cycling (Assayag et al. 2008; Jézéquel et al. 2012b), methane oxidation (Lopes et al. 2011), and bacterial community stratification (Lehours et al. 2005; Biderre-Petit et al. 2011). Inflows into the bottom layer of the lake of $\mathrm{Li}$-rich, ${ }^{14} \mathrm{C}$-free mineral waters with more negative $\delta^{18} \mathrm{O}$ values than surface waters (Jézéquel et al. 2012a; Assayag et al. 2008) together with the limited exchange of solutes (and heat) characterizing the steep gradient transition zone (chemocline) at $60 \mathrm{~m}$ depth (Aeschbach-Hertig et al. 2002) contribute to the persistence of a deep inorganic carbon reservoir that is ${ }^{14} \mathrm{C}$ depleted relative to atmospheric values. A simulation of DIC ${ }^{14} \mathrm{C}$ and $\delta^{13} \mathrm{C}$ profiles in the Lac Pavin monimolimnion using AquaSim at steadystate conditions allowed Jézéquel et al. (2012b) to determine the depth and flow of mineral water input that are used in this study. Improved knowledge of the water balance of the lake enabled the temporal evolution of the monimolinion structure to be modeled (AquaSim) by the progressive densification of the bottom waters over a period of several centuries (Jézéquel et al. 2012a). This feature is favorable for generating large ${ }^{14} \mathrm{C}$ age offsets for the organic material produced in the surface waters of the lake. Seasonal variations prevailing in the mixolimnion (surface to $60 \mathrm{~m}$ depth) required dynamic modeling as described below.

Sediments are laminated diatom oozes showing seasonal successions of thick, light diatom layers and thin, dark autumn layers (Schettler et al. 2007). Sedimentation in the 1990s is made of unusually thick diatom layers possibly reflecting anthropogenic influences (Schettler et al. 2007; Schwab et al. 2009). High-resolution seismic reflection and multibeam bathymetric surveys have highlighted a wide range of gravity reworking phenomena affecting the basin (Chapron et al. 2010, 2012).

\section{Previous Lac Pavin Radiocarbon Sediment Dating}

A weak deposit accumulation thickness was suggested by previous ${ }^{14} \mathrm{C}$ dates (Delibrias et al. 1972) obtained on bulk superficial Lac Pavin sediment sampled in a short core (1 m long). Without any age offset correction, the oldest ${ }^{14} \mathrm{C}$ dates found in that core (Gif-1261: $6050 \pm 145 \mathrm{BP}$; Gif-1263: $5770 \pm 140 \mathrm{BP}$ ) were considered to be roughly compatible with the age of the Pavin volcanic eruption at the origin of the crater lake, which is based on tephra chronology in peats (i.e. $7000 \mathrm{cal}$ BP or 6000 BP, Juvigné 1992). Deeper coring (Schwab et al. 2009, Chapron et al. 2010), varve counting (Stebich et al. 2005; Schettler et al. 2007), and sedimentation rate measurements (Martin et al. 1992) documented rates of up to $5 \mathrm{~mm} / \mathrm{yr}$ and the existence of a sediment deposit over $10 \mathrm{~m}$ thick in 


\section{Cycling and ${ }^{14}$ C Reservoir Effect in Lac Pavin}

the deepest area of the lake, demonstrating that surface sediment dates were affected by a large age offset. Coring this deposit down to the stony volcanic substratum gave a ${ }^{14} \mathrm{C}$ age of the presumed initial laminated diatom ooze layers of $\sim 6000 \mathrm{BP}$, suggesting no initial ${ }^{14} \mathrm{C}$ reservoir effect in the early lake conversely to the present day (Chapron et al. 2010).

\section{Sampling}

\section{Water Column}

Sampling of the water column was conducted in the central part of the lake at $92 \mathrm{~m}$ depth. Water samples for ${ }^{14} \mathrm{C}$ analysis of DOC and DIC and suspended particulate organic carbon $\left(\mathrm{POC}_{\text {susp }}\right)$ were pumped in situ (1-3 L) and on-line filtered $\left(450{ }^{\circ} \mathrm{C}\right.$ precombusted $\mathrm{GF} / \mathrm{F}$ filters) during 2 campaigns in June 2007 and July 2009. Filtered water samples for DIC were stored refrigerated in 1-L glass bottles filled without head space. DOC in acidified water samples $(2 \mathrm{~L}$ acidified with 100 drops of $\mathrm{H}_{3} \mathrm{PO}_{4} 75 \%$ per $\mathrm{L}$ ) was concentrated at $30-35^{\circ} \mathrm{C}$ in about $30 \mathrm{~mL}$ using a rotary evaporator. The concentrated solutions were then introduced into the combustion quartz tubes, dried overnight at $60^{\circ} \mathrm{C}$, and connected to the vacuum line for the $\mathrm{CO}_{2}$ production step (see below). Particulate matter on fiberglass filters related to $\mathrm{POC}_{\text {susp }}$ was rinsed with $\mathrm{H}_{3} \mathrm{PO}_{4}$ acidified water and dried overnight at $100{ }^{\circ} \mathrm{C}$. A $20-\mu \mathrm{m}$ mesh plankton net was used for vertical tows between the surface and 6 and $10 \mathrm{~m}$ depths in April 2007 and February 2008, respectively. Plankton material was rinsed with $\mathrm{HCl} \mathrm{10 \%}$ and dried. Sinking particles related to $\mathrm{POC}_{\text {sink }}$ were collected using a set of cylindrical sediment traps moored during 2 periods (July-August 2006 and November 2006-March 2007) at 4 different depths: $23,58,70$, and $88 \mathrm{~m}$. Particles collected by the traps were isolated by filtration $(\mathrm{GF} / \mathrm{F})$ and dried (Thiam 2009).

\section{Sediment}

Sampling of sediment material was made at mid-depth $(46 \mathrm{~m})$ and in the central deeper part of the lake $(90 \mathrm{~m}$ ) by short gravity coring (Chapron et al. 2012) and also 1 piston coring (PAV08 core at the 46-m-depth site) to reach the volcanic substratum underlying the sediment cover. Only the top section ( 1 meter long) and the bottom section ( $0.6 \mathrm{~m}$ long) of the $5-\mathrm{m}$-long piston core were used in this work given the presence of a thick disrupted slump layer in the middle section of the core (Chapron et al. 2010). Sediment material was used for ${ }^{14} \mathrm{C}$ analysis of sediment organic carbon (SOC) and macro-remains (tree leaves) when found.

\section{Radiocarbon Analysis}

Analyses were performed by accelerator mass spectrometry (AMS) either at the Poznan Radiocarbon Laboratory (Poland) for most sediment material (bulk sediment and leaf macro-remains) or at the LMC14 Artemis AMS facility (Saclay, Gif-sur-Yvette, France) for the water column samples and some bulk sediment samples (Tables 1 and 2). For analyses performed at the LMC14 accelerator, $\mathrm{CO}_{2}$ production and conversion to graphite targets were conducted at the IDES laboratory (Orsay University). Extraction of $\mathrm{CO}_{2}$ from DIC was done by adding $\mathrm{H}_{3} \mathrm{PO}_{4}$ and stripping water samples through a vacuum line. Conversion of organic carbon to $\mathrm{CO}_{2}$ was done at $850{ }^{\circ} \mathrm{C}$ in precombusted quartz tubes connected to the vacuum line (Louvat 1987). Complete combustion was ensured by a rapid rise in temperature and controlled by $\delta^{13} \mathrm{C}$ IRMS analysis of $\mathrm{CO}_{2}$ aliquots.

Pretreatment prior to the $\mathrm{CO}_{2}$ production step for plankton, $\mathrm{DOC}$, and $\mathrm{POC}_{\text {susp }}$ related samples was restricted to the acid treatments mentioned above. Bulk sediment (accounting for sediment organic carbon $\mathrm{SOC})$, sediment-trap $\left(\mathrm{POC}_{\text {sink }}\right)$, and macro-remains samples were analyzed either at the Saclay LMC14 facility or at the Poznań Radiocarbon Laboratory after acid-alkali-acid (AAA) pre- 


\section{$P$ Albéric et al.}

Table 1 Radiocarbon data for the water column and superficial sediment.

\begin{tabular}{|c|c|c|c|c|c|c|c|}
\hline $\begin{array}{l}\text { Sampling } \\
\text { location }\end{array}$ & $\begin{array}{l}\text { Sample } \\
\text { type }\end{array}$ & $\begin{array}{l}\text { Sampling } \\
\text { depth (m) }\end{array}$ & $\begin{array}{l}\text { Sampling } \\
\text { date }\end{array}$ & $\begin{array}{l}\text { Age } \\
\text { BP }\end{array}$ & $\begin{array}{l} \pm \\
1 \sigma\end{array}$ & $\begin{array}{l}\Delta^{14} \mathrm{C} \\
(\%)\end{array}$ & Lab nr \\
\hline Tributary & DIC & - & Feb 2008 & - & - & +44 & SacA-14138 \\
\hline Water column & DIC & 10 & June 2007 & 6630 & 35 & -565 & SacA-9602 \\
\hline Water column & DIC & 60 & June 2007 & 8785 & 40 & -667 & SacA-9603 \\
\hline Water column & DIC & 65 & June 2007 & 10,060 & 40 & -716 & SacA-9605 \\
\hline Water column & DIC & 70 & June 2007 & 9840 & 40 & -708 & SacA-9598 \\
\hline Water column & DIC & 75 & June 2007 & 9690 & 50 & -703 & SacA-9599 \\
\hline Water column & DIC & 80 & June 2007 & 9155 & 35 & -682 & SacA-9601 \\
\hline Water column & DIC & 85 & June 2007 & 8995 & 40 & -676 & SacA-9604 \\
\hline Water column & DIC & 90 & June 2007 & 8720 & 35 & -665 & SacA-9600 \\
\hline Water column & DIC & 5 & July 2009 & 120 & 30 & -22 & SacA-17966 \\
\hline Water column & DIC & 21 & July 2009 & 3355 & 30 & -346 & SacA-17965 \\
\hline Water column & DIC & 61 & July 2009 & 772 & 35 & -620 & SacA-17990 \\
\hline Water column & DIC & 71 & July 2009 & 992 & 40 & -711 & SacA-17963 \\
\hline Water column & DIC & 81 & July 2009 & 9070 & 60 & -679 & SacA-17967 \\
\hline Water column & DIC & 89 & July 2009 & 8630 & 40 & -661 & SacA-17968 \\
\hline Water column & DOC & 5 & July 2009 & 1900 & 60 & -217 & SacA-17966 \\
\hline Water column & DOC & 21 & July 2009 & 1810 & 130 & -207 & SacA-17965 \\
\hline Water column & DOC & 61 & July 2009 & 2010 & 170 & -227 & SacA-19675 \\
\hline Water column & DOC & 71 & July 2009 & 2730 & 130 & -294 & SacA-17999 \\
\hline Water column & DOC & 81 & July 2009 & 1630 & 100 & -189 & SacA-19672 \\
\hline Water column & $\mathrm{DOC}$ & 89 & July 2009 & 2940 & 140 & -311 & SacA-19669 \\
\hline Water column & $\mathrm{DOC}<5 \mathrm{KD}^{\mathrm{a}}$ & 89 & July 2009 & 3030 & 120 & -319 & SacA-19673 \\
\hline Water column & POC $_{\text {susp }}$ & 5 & July 2009 & 1880 & 60 & -214 & SacA-17987 \\
\hline Water column & POC $_{\text {susp }}$ & 5 & July 2009 & 1830 & 50 & -209 & SacA-17989 \\
\hline Water column & POC $_{\text {susp }}$ & 21 & July 2009 & 3475 & 45 & -356 & SacA-19674 \\
\hline Water column & POC $_{\text {susp }}$ & 61 & July 2009 & 4640 & 40 & -443 & SacA-17990 \\
\hline Water column & POC $_{\text {susp }}$ & 71 & July 2009 & 4420 & 30 & -427 & SacA-17994 \\
\hline Water column & POC $_{\text {susp }}$ & 81 & July 2009 & 4335 & 45 & -421 & SacA-17993 \\
\hline Water column & POC $_{\text {susp }}$ & 89 & July 2009 & 4325 & 30 & -420 & SacA-17988 \\
\hline Water column & Plankton & $0-6$ & Apr 2007 & 3210 & 35 & -334 & SacA-14130 \\
\hline Water column & Plankton & $0-10$ & Feb 2008 & 3605 & 35 & -366 & SacA-14131 \\
\hline Water column & $\mathrm{POC}_{\text {sink }}$ & 23 & July-Aug 2006 & 2040 & 40 & -230 & SacA-17997 \\
\hline Water column & $\mathrm{POC}_{\text {sink }}$ & 23 & Nov 2006-Mar 2007 & 2780 & 120 & -297 & SacA-17996 \\
\hline Water column & POC $_{\text {sink }}$ & 58 & July-Aug 2006 & 2470 & 30 & -270 & SacA-18002 \\
\hline Water column & $\mathrm{POC}_{\text {sink }}$ & 70 & July-Aug 2006 & 2480 & 30 & -271 & SacA-17999 \\
\hline Water column & $\mathrm{POC}_{\text {sink }}$ & 70 & Nov 2006-Mar 2007 & 1920 & 45 & -218 & SacA-17991 \\
\hline Water column & POC $_{\text {sink }}$ & 88 & July-Aug 2006 & 2450 & 30 & -268 & SacA-17998 \\
\hline $\begin{array}{l}\text { Lake bed } 46 \mathrm{~m} \\
(\text { PAV08-P1) }\end{array}$ & $\mathrm{SOC}$ & $(0.2-0.7)^{\mathrm{c}}$ & 2008 & 2070 & 40 & -233 & SacA-19655 \\
\hline $\begin{array}{l}\text { Lake bed } 91 \mathrm{~m} \\
\text { (PAV09-B1) }^{\mathrm{b}}\end{array}$ & SOC & $(0.5-1.0)^{\mathrm{c}}$ & 2009 & 2965 & 30 & -314 & SacA-28952 \\
\hline $\begin{array}{l}\text { Lake bed } 91 \mathrm{~m} \\
(\text { PAV09-B1) }\end{array}$ & SOC & $(1.0-1.5)^{\mathrm{c}}$ & 2009 & 2445 & 30 & -268 & SacA-28953 \\
\hline
\end{tabular}

$\mathrm{a}_{<}<\mathrm{kDa}$ DOC in ultrafiltrated water.

bWater depth and core section.

${ }^{\mathrm{c}}$ Sediment layer depth $(\mathrm{cm})$.

treatment (Goslar and Czernik 2000). AAA pretreatment applied to bulk biogenic sediment may cause the weight losses of a large proportion of the organic as well as of the bulk siliceous material (Olsson 2009). Humics from soils in the watershed of the lake are thought to make a very minor contribution to Lac Pavin and humic-like compounds present in sediment have rather a planktonic origin. One fortuitous replicate test done on bottom-core sediment with a milder alkaline attack gave a 


\section{Cycling and ${ }^{14}$ C Reservoir Effect in Lac Pavin}

${ }^{14} \mathrm{C}$ age that was $750 \mathrm{yr}$ older (Poz-48070 and Poz-45411, Table 2), suggesting a higher percentage of reservoir effect free aerial macrorests in the residual fraction. In this type of sediment, the proportion of residual organic fraction may be small, and given the aims of the present study, it might have been preferable to restrict pretreatment to the acid attack. However, the standard pretreatment procedure was retained for the purpose of comparison between tree leaves and bulk sediment material. The results of ${ }^{14} \mathrm{C}$ analyses (conventional ${ }^{14} \mathrm{C}$ ages) listed in Tables 1 and 2 are expressed later in the text using the $\Delta$ notation (Stuiver and Polach 1977; Stuiver 1980).

Table 2 Radiocarbon data for the buried sediment.

\begin{tabular}{|c|c|c|c|c|c|c|c|}
\hline $\begin{array}{l}\text { Core section } \\
\text { Water depth }\end{array}$ & $\begin{array}{l}\text { Sample } \\
\text { type }\end{array}$ & $\begin{array}{l}\text { Sediment layer } \\
\text { depth }(\mathrm{cm})\end{array}$ & $\begin{array}{l}\text { Sampling } \\
\text { date }\end{array}$ & $\begin{array}{l}\text { Age } \\
\text { BP }\end{array}$ & $1 \sigma$ & $\begin{array}{l}\Delta^{14} \mathrm{C} \\
(\%)\end{array}$ & Lab nr \\
\hline PAV09-B1 $91 \mathrm{~m}$ & SOC & $94-94.5$ & 2009 & 6170 & 50 & -540 & SacA-19657 \\
\hline PAV09-B1 $91 \mathrm{~m}$ & Leaves & 96.5 & 2009 & 150 & 35 & -25 & Poz-33126 \\
\hline PAV09-C2 $45 \mathrm{~m}$ & SOC & $34.5-35.5$ & 2009 & 4130 & 45 & -406 & SacA-19660 \\
\hline PAV09-C2 45 m & Leaves & 35 & 2009 & 155 & 40 & -26 & SacA-19662 \\
\hline PAV08-1A1 46 m & $\mathrm{SOC}$ & $3-4$ & 2008 & 5205 & 45 & -481 & SacA-19656 \\
\hline PAV08-1A1 46 m & $\mathrm{SOC}$ & $22.5-23.5$ & 2008 & 3765 & 35 & -379 & Poz-31852 \\
\hline PAV08-1A1 46 m & Leaves & 23 & 2008 & 1210 & 60 & -146 & Poz-31851 \\
\hline PAV08-2A1 46 m & $\mathrm{SOC}$ & $70.5-71.5$ & 2008 & 5960 & 50 & -527 & SacA-19658 \\
\hline PAV08-2A1 46 m & Leaves & 71 & 2008 & 1290 & 35 & -154 & Poz-27046 \\
\hline PAV08-2A1 $46 \mathrm{~m}$ & SOC & $96.5-97.5$ & 2008 & 6795 & 45 & -574 & SacA-19659 \\
\hline PAV08-2A1 46 m & Leaves & 97 & 2008 & 1430 & 30 & -169 & Poz-27047 \\
\hline PAV08-2B2 $46 \mathrm{~m}$ & SOC & $441-442$ & 2008 & 7620 & 50 & -613 & Poz-45411 \\
\hline PAV08-2B2 $46 \mathrm{~m}$ & SOC & $441-442$ & 2008 & 8370 & 50 & -647 & Poz-48070 \\
\hline PAV08-2B2 46 m & SOC & $450-451$ & 2008 & 5865 & 35 & -518 & Poz-45413 \\
\hline PAV08-2B2 $46 \mathrm{~m}$ & SOC & $460-461$ & 2008 & 6580 & 40 & -559 & Poz-45414 \\
\hline
\end{tabular}

\section{Radiocarbon Cycle Modeling}

Modeling the ${ }^{14} \mathrm{C}$ composition of particulate organic carbon $\left(\mathrm{POC}_{\text {sink }}\right)$ formed in the surface water column and sedimenting to lake bottom was tested using the AquaSim software (Reichert 1994, 1998). Using this software, Lopes et al. (2011) developed a detailed reactive transport model describing biogeochemical processes applicable to Lac Pavin. Key issues of importance in the model settings and relevant to the present modeling attempt are the following: depth distribution of vertical mixing coefficients $\left(\mathrm{K}_{(\mathrm{z})}\right)$ that govern mixing due to eddy diffusion; discharge of water inflows in the lake depths that govern advection in the water column; concentration of inflowing dissolved compounds; transformation rates; diffusion coefficients in porewaters that determine benthic fluxes; $\mathrm{CO}_{2}$ exchange rate at the lake surface; and sedimentation velocity of the particles. Biogeochemical and physical processes are expressed by a set of partial differential transport-reaction equations solved for each dissolved and particulate state variable with a vertical resolution of $1 \mathrm{~m}$. Each chemical process is characterized by a specific rate constant (possibly variable with time and depth) and stoichiometric coefficients.

Attempting to simulate in detail DIC and $\mathrm{POC}{ }^{14} \mathrm{C}$ in time and depth in surface waters would have been far beyond the possibilities of this work. Due to biological and environmental variability, photosynthetic production in aquatic systems is subjected to too many factors: for instance, seasonal or even daily depth variation in maximum photosynthesis yields in a photic zone extending down to $30 \mathrm{~m}$ depth (Amblard and Bourdier 1990); or recycling of carbon by bacterial re-assimilation and 


\section{$P$ Albéric et al.}

protistan bacterivory in the metalimnion (thermocline layer) (Maurin et al. 1997; Carrias et al. 1998) where the DIC $\Delta^{14} \mathrm{C}$ gradient is the steepest (see below). Furthermore, sufficient field data to be compared with model outputs would have been in any case lacking. The objectives of the modeling approach were to fix a limited number of parameters, in accordance with knowledge acquired in the field and previous modeling attempts, that would give schematic ${ }^{14} \mathrm{C} \mathrm{POC}_{\text {sink }}$ values within the range of observed modern offset values. Then, by changing the length of seasons (each characterized by a defined $\mathrm{K}_{(\mathrm{z})}$ depth distribution in the mixolimnion, see below), different scenarios leading to a larger contribution of deeper DIC providing model outputs compatible for larger reservoir effects were tested.

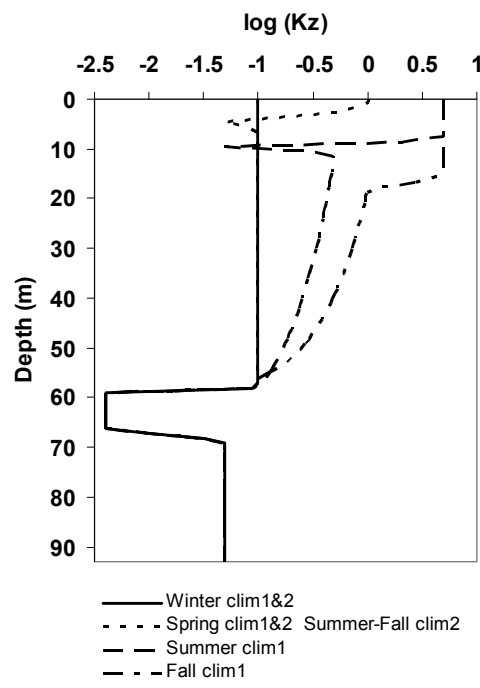

Figure 1 Eddy diffusion coefficient $\left(\mathrm{K}_{(\mathrm{z})}\right)$ versus depth for the 4 seasons defined scenario compatible with modern day reservoir effect (Climate 1 ) and for an alternative scenario (Climate 2) for which a larger contribution of deeper DIC would provide a model compatible with larger past reservoir effects (see Figures 5 and 6).

Transformation mechanisms and state variables were limited to photosynthesis (POC production from DIC), respiration (POC mineralization to DIC), methanogenesis (POC fermentation to DIC and $\left.\mathrm{CH}_{4}\right)$, and methane-oxidation $\left(\mathrm{CH}_{4}\right.$ transformation to DIC). Each component or compound was represented by 2 state variables accounting for ${ }^{12} \mathrm{C}$ and ${ }^{14} \mathrm{C}$ chemical species. Translocation of carbon between compounds was operated at constant $\Delta^{14} \mathrm{C}$ values. POC respiration and methane oxidation were localized in the mixolimnion and the chemocline. Methanogenesis was restricted to the sediment. $\mathrm{CO}_{2}$ exchange between air and surface waters was adjusted at each model step proportionally to the difference between DIC and atmospheric $\mathrm{CO}_{2}$. POC production in surface waters was adjusted according to the organic carbon export values defined by Lopes et al. (2011). The methanogenesis rate controlling methane and DIC fluxes from the sediment was kept constant with time and adjusted to be compatible to quasi steady-state ${ }^{14} \mathrm{C}$ compositions (DIC) and concentrations (DIC, $\mathrm{CH}_{4}$ ) observed in the monimolimnion (this work; Lopes et al. 2011; Jézéquel et al. 2012b). $\mathrm{K}_{(\mathrm{z})}$ values, which depend on (and can be computed from) density gradients through the water column, were fixed (see Figure 1) in accordance with previous work (Aeschbach-Hertig et al. 2002; Lopes et al. 2011). The monimolimnion $\mathrm{K}_{(\mathrm{z})}$ value was maintained constant over the year $\left(0.05 \mathrm{~m}^{2} /\right.$ day) while the $\mathrm{K}_{(\mathrm{z})}$ value at the chemocline (59-65 $\mathrm{m}$ depth) was fixed at $0.004 \mathrm{~m}^{2} / \mathrm{day}$. Accounting for the presence of an ice cover, the winter period was defined by a constant and small $\mathrm{K}_{(\mathrm{z})}$ value $\left(0.1 \mathrm{~m}^{2} /\right.$ day) through the entire mixolimnion water column and by organic carbon export values $<10^{-5} \mathrm{~mol} / \mathrm{m}^{3} /$ day. The spring period differed from winter by the presence of a rather thin epilimnion (surface $\mathrm{K}_{(\mathrm{z})} 1 \mathrm{~m}^{2} /$ day) limited by a shallow thermocline $\left(\mathrm{K}_{(\mathrm{z})} 0.05 \mathrm{~m}^{2} /\right.$ day at $4 \mathrm{~m}$ depth) and a POC 


\section{Cycling and ${ }^{14}$ C Reservoir Effect in Lac Pavin}

maximum yield around $5 \mathrm{~m}$ depth $\left(4 \times 10^{-3} \mathrm{~mol} / \mathrm{m}^{3} /\right.$ day $)$. The summer period thermocline was set at $10 \mathrm{~m}$ depth and the photosynthetic maximum between 11 and $17 \mathrm{~m}$ depth, yielding $\sim 3 \times 10^{-3} \mathrm{~mol} /$ $\mathrm{m}^{3} /$ day. Finally, the fall period was characterized by a deeper extension of high $\mathrm{K}_{(\mathrm{z})}$ values $\left(5 \mathrm{~m}^{2} /\right.$ day) down to $18 \mathrm{~m}$ depth due to the vanishing of the thermocline, and a POC export around $10^{-3}$ $\mathrm{mol} / \mathrm{m}^{3} /$ day. Mean depth inputs and inflows of underground and surface waters as well as atmospheric precipitations were also kept constant over the year. The POC sedimentation velocity in Lac Pavin, which may vary from 1.5 to $6 \mathrm{~m} /$ day (Lopes et al. 2011), was fixed at $2 \mathrm{~m} /$ day. Calculation was conducted over $27 \mathrm{yr}$ to reach quasi steady-state conditions at the decadal scale.

\section{RESULTS AND DISCUSSION}

\section{Water Column and Superficial Sediment}

Depth profiles of basic parameters (temperature $\mathrm{T}$, dissolved $\mathrm{O}_{2}$, and specific conductivity $\mathrm{C} 25$ ) obtained in June 2007 and July 2009 during 2 sampling campaigns are shown in Figure 2. The deep anoxic layer, limited by the steep $\mathrm{C} 25$ gradient chemocline, represents the monimolimnion, and is assumed to be in a quasi steady-state for several hundred years (Jézéquel et al. 2012a). Overlying layers from the surface to $60 \mathrm{~m}$ depth (combined as mixolimnion) experience summer thermal stratification and fall overturn with variable yearly intensity. June 2007 represents a situation following a warm and windy winter with only a few days of ice covering of the lake surface. This led to a greater mixing in the water column down to $60 \mathrm{~m}$ depth together with a sharper transition between the mixo- and monimolimnion (Figure 2a). July 2009 followed a cold winter with a long freezing period, which explains the upward moving of the anoxic limit above $60 \mathrm{~m}$ depth (Figure $2 \mathrm{~b}$ ) and the smoothing of $\mathrm{T}$ and $\mathrm{C} 25$ profiles across the transition.

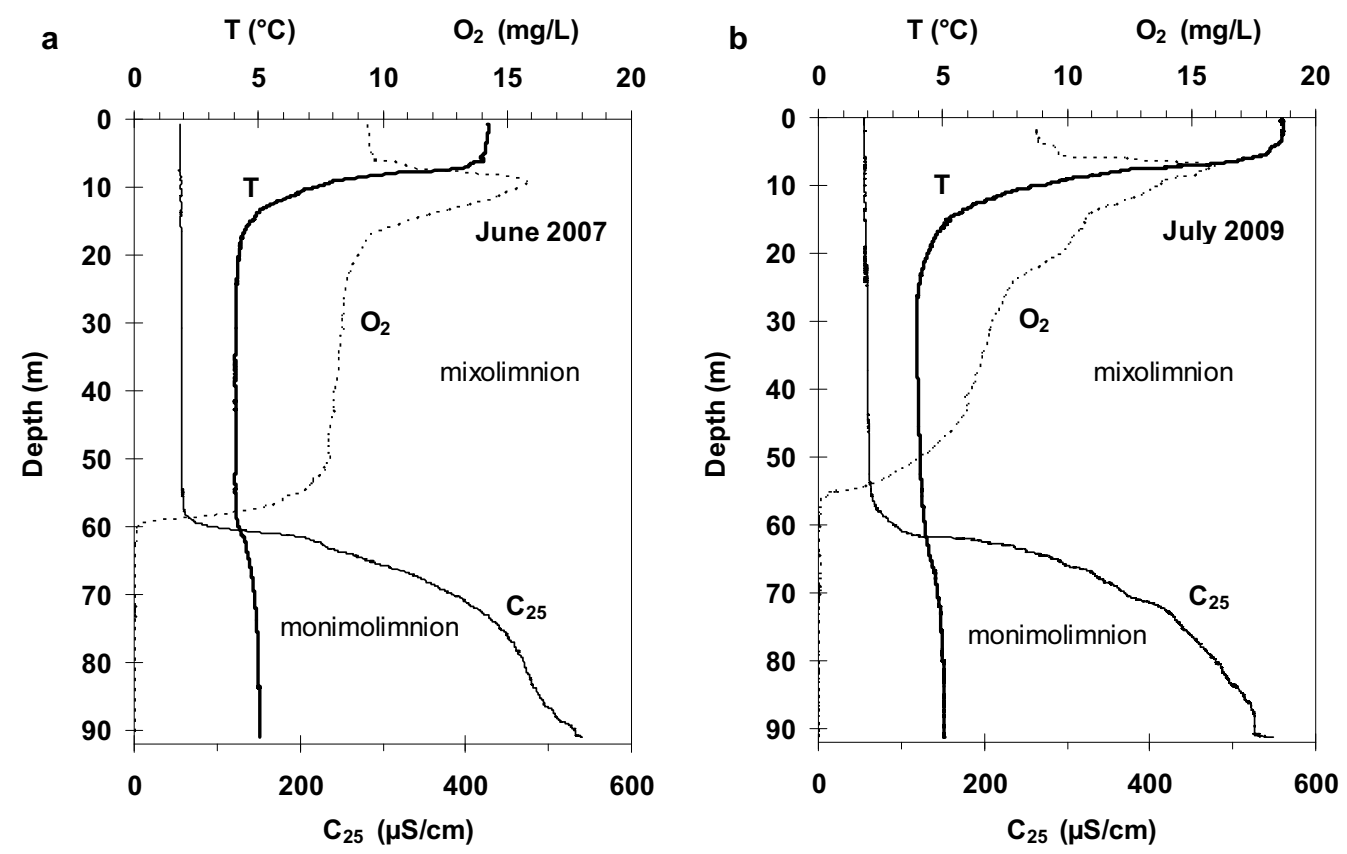

Figure 2 Depth profiles for $\mathrm{T}\left({ }^{\circ} \mathrm{C}\right)$, dissolved $\mathrm{O}_{2}(\mathrm{mg} / \mathrm{L})$, and specific conductivity at $25^{\circ} \mathrm{C}(\mathrm{C} 25, \mu \mathrm{S} / \mathrm{cm})$ during the 2 principal sampling campaigns for ${ }^{14} \mathrm{C}$ analyses: a) June 2007; b) July 2009. 


\section{$P$ Albéric et al.}

Water column ${ }^{14} \mathrm{C}$ results are compiled in Table 1 and summarized in Figure 3. DIC $\Delta^{14} \mathrm{C}$ values were up to $700 \%$ more negative in the water column when compared with atmospheric and creek values. Profiles in the monimolimnion were almost identical for the 2 sampling sets in accordance with the steady state of that stratum. Minimum values were found at a depth of $\sim 65 \mathrm{~m}$. Combined with a water balance of the lake based on $\delta^{18} \mathrm{O}$ data (Jézéquel et al. 2012a) and the $\mathrm{Li} / \mathrm{Na}$ ratio, DIC ${ }^{14} \mathrm{C}$ profiles were modeled in accordance with a dead carbon carbo-gaseous mineral water inflow of $\sim 130 \mathrm{~m}^{3} \mathrm{~d}^{-1}$ at $68 \mathrm{~m}$ depth (Jézéquel et al. 2012b).

The main result concerning organic carbon pools was the limited $\Delta^{14} \mathrm{C}$ range (compared to DIC) for superficial SOC, either at mid-depth or at bottom (respectively at 46 and $91 \mathrm{~m}$ depth, Table 1 and Figure 3), and $\mathrm{POC}_{\text {sink }}$ through the whole water column. The mean $\Delta{ }^{14} \mathrm{C}$ value and amplitude of variation for the modern biogenic sedimentary flux $(\sim-263 \pm 48 \%)$ accounts, however, for a mean age offset of $\sim 2500 \pm 500{ }^{14} \mathrm{C}$ yr. Adding DOC in the comparison does not make a significant statistical difference to the mean value $(-258 \pm 65 \%)$ but slightly increases the range of variation of organic $\Delta^{14} \mathrm{C}$ in the water column. This observation accords with DOC concentration increasing (up to $20 \mathrm{mg} / \mathrm{L}$ ) down the monimolimnion as a result of SOC transformation in the superficial sediment and upward migration of solutes (Albéric et al. 2000). Comparing plankton and suspended POC $\left(\mathrm{POC}_{\text {susp }}\right.$ ) to the modern biogenic flux $\Delta^{14} \mathrm{C}$ range defined above ( $\mathrm{DOC}+\mathrm{POC}_{\text {sink }}$ average, approximately $-260 \pm 60 \%$ ) gave 2 distinct cases. The upper mixolimnion samples had values within or close to the modern range (plankton and $\mathrm{POC}_{\text {susp }}$ at $21 \mathrm{~m}$ depth were however 50\% more negative than the minimum range value, a possible consequence of acid-only pretreatment). Average monimolimnion $\mathrm{POC}_{\text {susp }}$ samples were closer to $-428 \pm 10 \%$, a value that is significantly more negative and could be attributed to different ways of organic matter production that exist in surface waters. Material sampled at these depths was made of gray sulfide particles supporting methanotrophic or sulfo-oxidant autotrophic bacteria (Lehours et al. 2005; Biderre-Petit et al. 2011), which may partly rely on the more $\Delta^{14} \mathrm{C}$ negative inorganic carbon sources present in the monimolimnion. The AMS $\delta^{13} \mathrm{C}$ value for $\mathrm{POC}_{\text {susp }}$ sampled at $60 \mathrm{~m}$ depth $(-40 \%)$ supports this hypothesis when compared to shallower or deeper samples $(-25 \%)$.

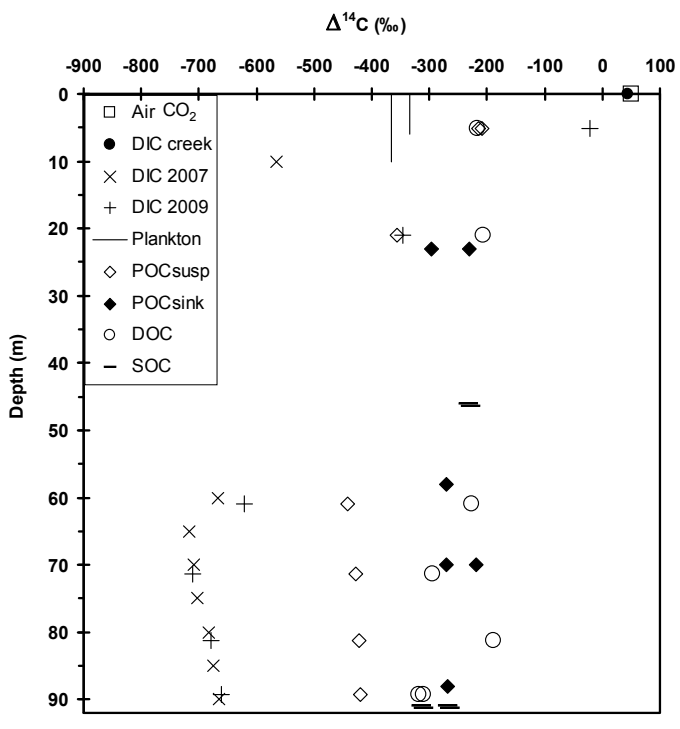

Figure $3 \Delta \Delta^{14} \mathrm{C}$ depth profiles. Plankton was sampled in April 2007 and February 2008 from surface to 6-10 m water depth; DIC water column in June 2007 and July 2009; DIC creek in February 2008; POC $_{\text {susp }}$ and DOC in July 2009; POC $_{\text {sink }}$ in July-August 2006 and November 2006-March 2007; SOC lake bed at 46 and $91 \mathrm{~m}$ depth in 2008 and 2009, respectively. Air $\mathrm{CO}_{2}$ value deduced from annual mean atmospheric trend (Levin and Kromer 2004). 


\section{Cycling and ${ }^{14}$ C Reservoir Effect in Lac Pavin}

Spatial variability of top-core sediments was addressed by only 2 samplings, one at mid-depth under oxic bottom water conditions and the other in the central part of the lake with anoxic conditions. The $\Delta^{14} \mathrm{C}$ difference of top-core SOC did not depart from the range of values defining modern biogenic sedimentary fluxes, suggesting a weak influence of the redox conditions on the ${ }^{14} \mathrm{C}$ signature. Bulk sediment $\Delta{ }^{14} \mathrm{C}$ difference between adjacent 0.5 -cm sediment layers at the top of the PAV09-B1 core section (Table 1) exceeds the redox difference and probably rather reflects variation in the age offset of the biogenic surface production than SOC compositional differences as observed lake-wide (Zigah et al. 2012b). Increasing the proportion of terrestrial organic inputs would tend to give less negative (younger) bulk sediment $\Delta^{14} \mathrm{C}$ values, provided that the age of (re)sedimented debris does not exceed the age offset characterizing the modern water column biogenic flux $\left(2500 \pm 500{ }^{14} \mathrm{C} \mathrm{yr}\right)$.

\section{Buried Sediment}

As discussed above, SOC in bulk superficial sediments had $\Delta{ }^{14} \mathrm{C}$ values from about -220 to $-320 \%$ (Table 1), consistent with the values of the water column sedimentary flux and leading to a modern age offset of $\sim 2500 \pm 500{ }^{14} \mathrm{C}$ yr. The depth-age relation for core section PAV09-B1 is based on the varve counting depth-age model proposed by Schettler et al. (2007). For the core section PAV09-C2, the single point SOC age was directly compared to that of the macro-remains sampled at the same level (Table 2). For the top sections of the piston core PAV08-1A1 and -2A1, the depth-age model relies on macro-remains dates and modern age for the top layer (Chapron et al. 2010). For the bottom section of the piston core (PAV08-2B2, with no macro-remains), the depth-age model assumed $\sim 6000 \mathrm{BP}$ for the volcanic layer underlying the deposit bed and an accumulation rate of $1 \pm$ $0.5 \mathrm{~mm} / \mathrm{yr}$ (compatible with the mean value given by Schettler et al. 2007 and the compaction effect). The period $1500-5500 \mathrm{BP}$ was not documented due to the presence of the thick slump deposit. In most cases, SOC $\Delta^{14} \mathrm{C}$ values in buried sediments (Table 2) were not supported by depthage model ages, even those corrected by a modern reservoir effect. Differences between $\Delta^{14} \mathrm{C}$ depthage model values and measured bulk sediment SOC values are plotted in Figure 4 versus depth-age model ${ }^{14} \mathrm{C}$ ages of the layers in chronological order. Although $1 \Delta^{14} \mathrm{C}$ offset at $\sim 1300 \mathrm{BP}$ compares well with the present mean value (Figure 4), most calculated offsets for the top section first meter were found in the -400 to $-500 \%$ range, corresponding to a 4000 - to 6000 -yr reservoir effect. This could potentially indicate that the lake reservoir effect experienced large fluctuations during the last millennium. In the early period of lake formation, the offset remained nearly zero during the time of deposition of the $25 \mathrm{~cm}$ bottom sediment. Nevertheless, the occurrence of an apparent offset of about $-100 \%$ at $35 \mathrm{~cm}$ from the bottom (PAV08-2B2 441-442 cm layer, Table 2) suggests the beginning of carbon recycling in the lake system. As mentioned above, the difference in alkaline pretreatment may account for the variability observed within that replicate (Table 2).

\section{Modeling}

Modeling present conditions (henceforth Climate 1 ) was done by alternating 4 seasonal yearly periods each defined (see Materials and Methods) by specific $\mathrm{K}_{(\mathrm{z})}$ profiles (Figure 1) and photosynthesis conditions (depth of maximum yields). Results are summarized in Figures 5 and 6. Model outputs for $\Delta^{14} \mathrm{C}$ DIC are plotted versus depth for every month of year 24 (Figure 5a) and versus dates (years 24 to 26) for several depths (Figure $5 \mathrm{c}$ ). $\Delta{ }^{14} \mathrm{C} \mathrm{POC}_{\text {sink }}$ values plotted versus dates (years 24 to 26) satisfactorily bracket available data inside the current -200 to $-300 \%$ range (Figure 6 ). The goal was to establish a credible alternative scenario fitting the -400 to $-500 \%$ range (see Figure 4 ) by considering mechanisms that increase ${ }^{14} \mathrm{C}$-depleted DIC rising from deep waters to the surface or by minimizing atmospheric $\mathrm{CO}_{2}$ inputs. Modeling attempts to simulate more complete mixing of mixolimnion waters during fall and winter did not succeed in decreasing the ${ }^{14} \mathrm{C}$ contents of photosyn- 


\section{P Albéric et al.}

Figure $4 \quad \Delta^{14} \mathrm{C}$ offset between measured bulk sediment organic carbon (SOC) values and depth-age model values versus depth-age model ${ }^{14} \mathrm{C}$ ages in sediment cores. Uncertainty in the sedimentation rate at the bottom of the core is shown by the error bars.

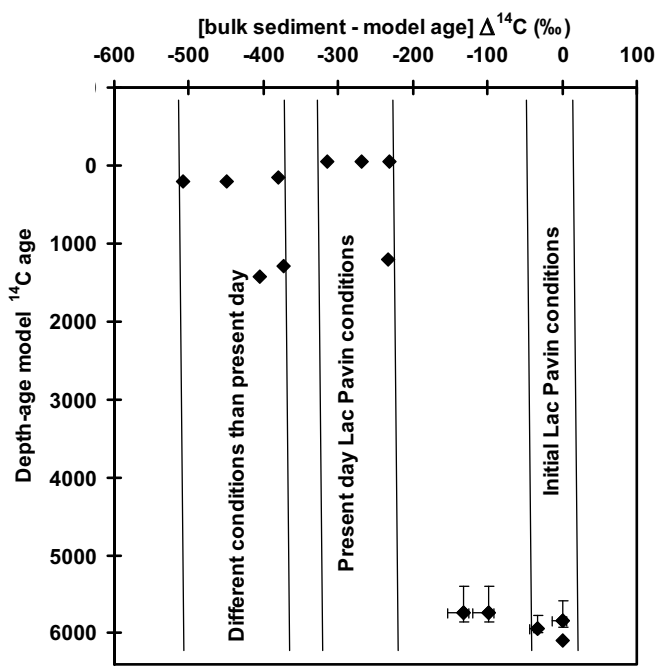

thetic zone DIC and thus $\mathrm{POC}_{\text {sink }}$ (results not shown). Increasing mixing seems rather to enhance atmospheric $\mathrm{CO}_{2}$ penetration in the water column, although the air-water compartment is certainly the least constrained by the model and available data. Therefore, the validity of the single very negative $\Delta^{14} \mathrm{C}$ DIC data $(-565 \%$ ) found at $10 \mathrm{~m}$ depth in June 2007 (following a greater mixing period in winter, see Figure 2), which seems to contradict the model and organic carbon water column data, is perhaps questionable. For the purpose of demonstration, a simple scenario with only 2 seasons was defined, corresponding to an alternative climate with a cooler summer than the present day. In such a scenario, the thermal stratification of the mixolimnion during cool summer and fall periods was chosen to fit Climate 1 spring conditions while keeping POC export characteristics unchanged. All other conditions (creek and underwater-spring input flows, interface exchanges) were kept identical. The results depicted as Climate 2 in Figure $5 \mathrm{~b}$ and $5 \mathrm{~d}$ and Figure 6 illustrate a possible type of weather change corresponding to lesser mixing of the mixolimnion and in accordance with the lower $\Delta^{14} \mathrm{C}$ values found in some core sections of the sediment (Figure 4). However, other mechanisms or a different timing of alternating stratification and mixing periods could also cause such a large offset but would require more complex scenarios.

In addition to the scenarios studied in this section, which rely mainly on variation in seasonal stratification and POC production and export in surface waters, several different types of mechanisms could be considered: (1) Climatic variations of atmospheric precipitations and underground water inflows impacting the deep mixolimnion chemical stratification as inferred by Schettler et al. (2007) from varved sediment studies; (2) Massive slumps of sediment (Chapron et al. 2010) that could have a several-year effect on the water column stratification and carbon recycling; (3) Possible related events such as gas outbursts or overflows described in other maar lakes (De Benedetti et al. 2008; Caracausi et al. 2009) could also represent major perturbations to the ${ }^{14} \mathrm{C}$ budget. By modifying the chemical stratification of the lake and meromictic conditions, these mechanisms may have a more drastic impact than the variability depicted by the Climate 1 and 2 model scenarios.

\section{Understanding the Apparent Past Reservoir Effect in Lac Pavin}

Estimation of the apparent past ${ }^{14} \mathrm{C}$ offset was calculated by the difference between the bulk $\Delta{ }^{14} \mathrm{C}$ SOC value and the conventional depth-age model value (Figure 4). The choice of sample pretreatment procedure may be critical on ${ }^{14} \mathrm{C}$ results (Olsson 2009) but was not explored in detail during 

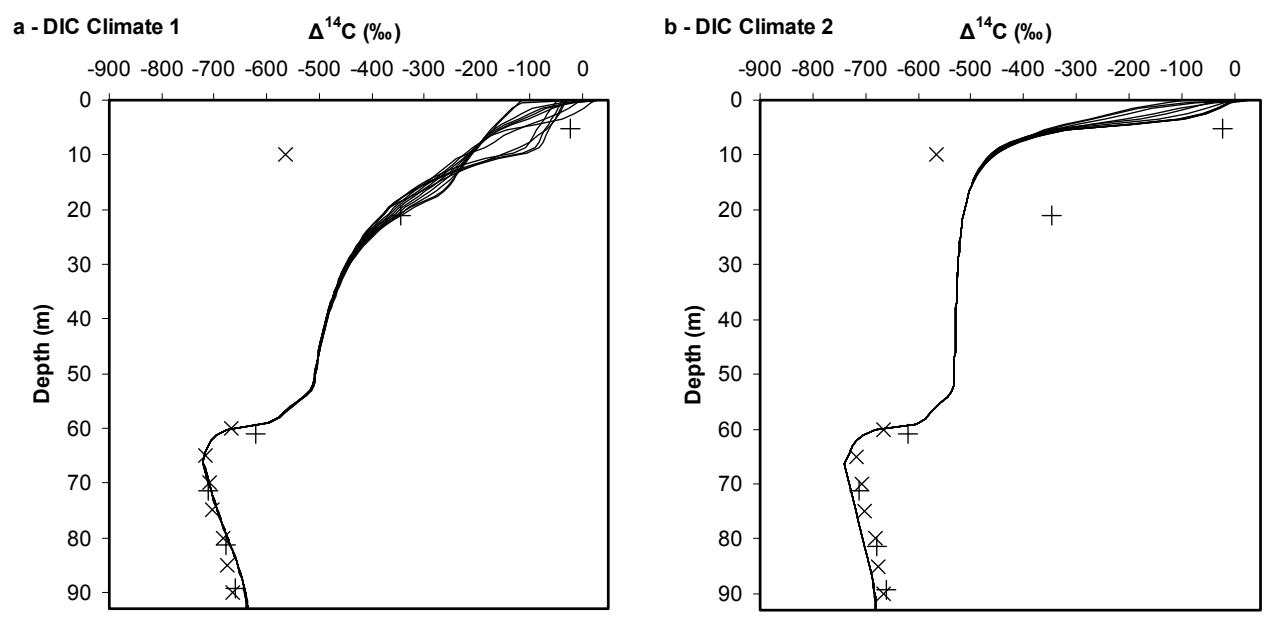

c - DIC Climate 1

d - DIC Climate 2
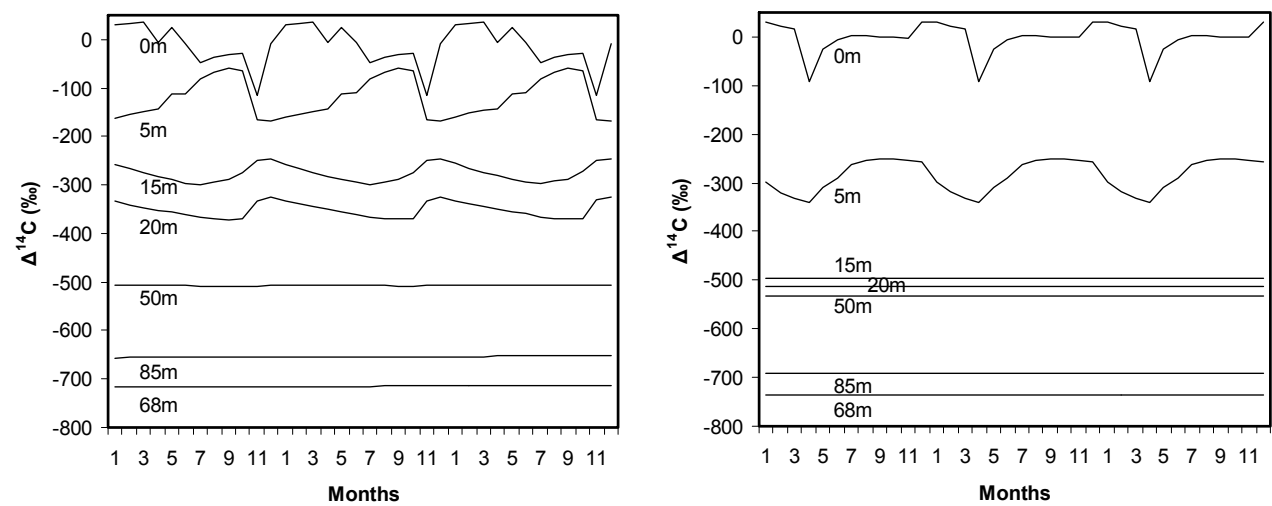

Figure 5 Model outputs for DIC $\Delta^{14} \mathrm{C}$ versus depth for each month of the year: (a) Climate 1 and (b) Climate 2 scenarios. Idem versus time at different depths, (c) Climate 1; (d) Climate 2. Climate 1 represents modern conditions. Climate 2 represents climatic conditions having a cooler summer (shallower summer thermal stratification). Cross plot marks in (a) and (b) are Figure 3 DIC data for comparison.

this study. Since sediment material in Lac Pavin is mostly composed of autochthonous material, humic-like fractions extracted by hydroxide will not reflect terrestrial contamination but rather will contain the information that is being sought. It is the insoluble fraction that may risk being contaminated by terrestrial plant remains. The question may be not pertinent for water column samples that gave ${ }^{14} \mathrm{C}$ values within the same range, whether treated with hydroxide or not. However, buried sediment past reservoir effect estimations based on untreated bulk sediment might be possibly greater. The terrestrial plant fraction was assumed to be negligible in Lac Pavin diatom ooze whole sediment as confirmed by Rock-Eval pyrolysis (data not shown), but microscopic observations may add further useful information on this issue.

Interannual variations in mixing intensity in the mixolimnion as depicted in Figure 2, which may impact exchange and reactivity of chemicals through the chemocline (e.g. dissolved $\mathrm{O}_{2}$ ), have to be understood as minor fluctuations within a given climate pattern without major repercussions on the age offset of the organic matter produced or consecutive dietary reservoir effect (Fernandes et al., 


\section{$P$ Albéric et al.}

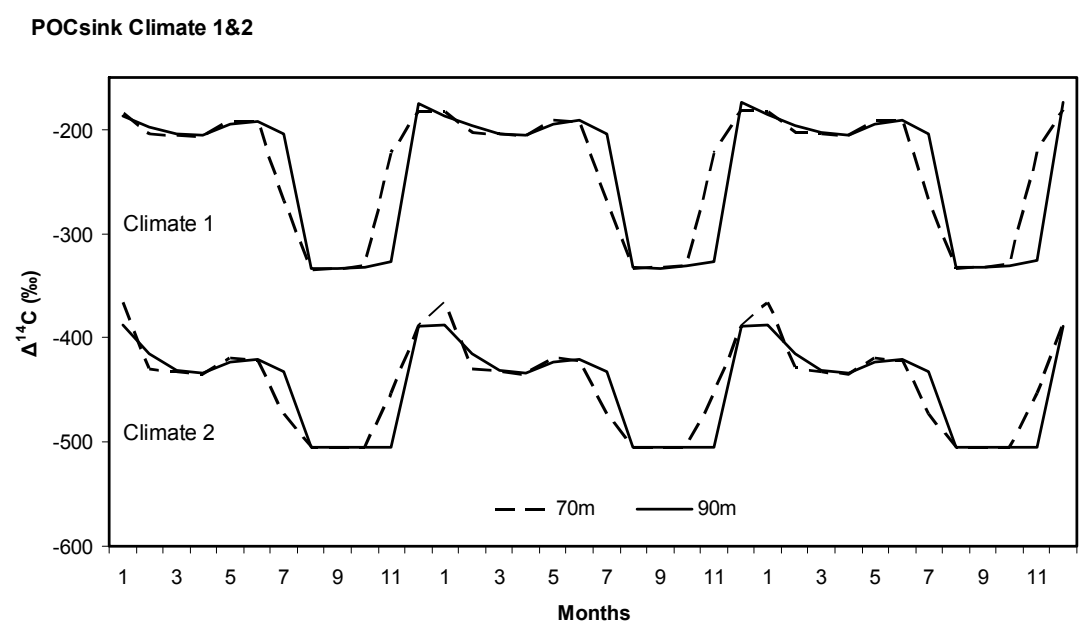

Figure 6 Model $\Delta^{14} \mathrm{C}$ versus time for POC produced in surface waters according to 2 different climate scenarios at 70 and $90 \mathrm{~m}$ depth. Climate 1 represents modern conditions. Climate 2 represents climatic conditions having a cooler summer (shallower summer thermal stratification).

these proceedings). Conversely, the difference between the Climate 1 and 2 scenarios, even though quite small, persisted durably over dozens of years.

Deep bacterial production in the monimolimnion if rightly represented by $\mathrm{POC}_{\text {susp }}$ samples seems characterized by greater offset values than algal surface production. Although, monimolimnion carbon export appears far lower than surface export (Thiam 2009), which could have been otherwise in different past conditions and may have contributed more largely to the reservoir effect.

The position of the chemocline around $60 \mathrm{~m}$ depth and the characteristics of the monimolimnion act in Lac Pavin as a reservoir effect amplifier tuned by the seasonal stratification of the mixolimnion. The link between meromicticity and high offset values may be addressed schematically (with no attempts to model change in geochemistry like in Moreira et al.2011) by eliminating the chemocline (i.e. extending high $\mathrm{K}_{(\mathrm{z})}$ values down to the bottom). Although very shallow POC production will have the same ${ }^{14} \mathrm{C}$ signature, strong holomicticity will mostly erase any reservoir effect in the lake (result not shown). As according to Jézéquel et al. (2012a), the transition from holomicticity to meromicticity will take at least $200 \mathrm{yr}$, detecting sediment deposited during possible holomictic periods seems to be achievable, provided that a fairly continuous sampling of sediment laminae is carried out. So far, this was found only for layers sampled at the base of the core, which are assumed to represent the early period of lake formation estimated to have lasted for at least a few hundred years (Figure 4).

\section{CONCLUSIONS}

The data presented in this paper on different organic carbon pools in the water column and bed sediments of Lac Pavin document a contemporary $\Delta^{14} \mathrm{C}$ offset in the range -200 to $-300 \%$, corresponding to an average age reservoir effect of $\sim 2500 \mathrm{yr}$. This relatively uniform value found through the water column at different collection dates may be considered as a mean value integrating the complexity of organic matter production in surface waters. This rather large reservoir effect results from the physical structure of the lake by meromicticity and storage of dead carbon in the monimolimnion.

During the last millennium, offset values deduced from the sedimentary record may have been much larger $(-500 \%$ ), but almost zero at the early formation history of the lake $7000 \mathrm{yr}$ ago. Modeling 


\section{Cycling and ${ }^{14}$ C Reservoir Effect in Lac Pavin}

attempts have allowed us to define a seasonal scenario capable of predicting modern conditions and to test different scenarios for which there is a larger contribution of deeper DIC, compatible with larger past reservoir effects. The conclusion is that variation of SOC $\Delta^{14} \mathrm{C}$ in laminated lake sediments is certainly an interesting proxy to study the history of lake systems such as Lac Pavin, but at least 2 future lines of research should be followed to more adequately model and understand past reservoir effect variations: (1) obtaining more data on the dynamics of the ${ }^{14} \mathrm{C}$ composition of plankton; and (2) carefully sampling laminated sediment layers to study continuous deposit sequences instead of discrete distant levels.

\section{ACKNOWLEDGMENTS}

${ }^{14} \mathrm{C}$ analysis benefited from funding by INSU-CNRS at the Artemis facility (CEA-Saclay) and by DREAL63. Fieldwork was facilitated thanks to accommodation at the Besse biological station (Université Blaise Pascal, Clermont-Ferrand). This work was part of the METANOX project funded by ANR-EC2CO. We thank Ricardo Fernandes and Christine Hatté for constructive comments.

\section{REFERENCES}

Aeschbach-Hertig W, Hofer M, Schmid M, Kipfer R, Imboden DM. 2002. The physical structure and dynamics of a deep, meromictic crater lake (Lac Pavin, France). Hydrobiologia 487:111-36.

Albéric P, Viollier E, Jezequel D, Grosbois C, Michard G. 2000. Interactions between trace elements and dissolved organic matter in the stagnant anoxic deep layer of a meromictic lake. Limnology and Oceanography 45:1088-96.

Amblard C, Bourdier G. 1990. The spring bloom of the diatom Melosira italica subsp. subarctica in lake Pavin: biochemical, energetic and metabolic aspects during sedimentation. Journal of Plankton Research 12:645-60.

Ascough PL, Cook GT, Church MJ, Dunbar E, Einarsson A, McGovern TH, Dugmore AJ, Perdikaris S, Hastie A, Fridriksson A, Gestsdottir H. 2010. Temporal and spatial variations in freshwater ${ }^{14} \mathrm{C}$ reservoir effects: Lake Mývatn, northern Iceland. Radiocarbon 52(3): 1098-112.

Assayag N, Jézéquel D, Ader M, Viollier E, Michard G, Prévot F, Agrinier P. 2008. Hydrological budget, carbon sources and biogeochemical processes in Lac Pavin (France): constraints from $\delta^{18} \mathrm{O}$ of water and $\delta^{13} \mathrm{C}$ of dissolved inorganic carbon. Applied Geochemistry 23:2800-16.

Biderre-Petit C, Boucher D, Kuever J, Albéric P, Jézéquel D, Chebance B, Borrel G, Fonty G, Peyret P. 2011. Identification of sulfur-cycle prokaryotes in a low-sulfate lake (Lake Pavin) using aprA and 16S rRNA gene markers. Microbial Ecology 61:313-27.

Caracausi A, Nuccio M, Favara R, Nicolosi M, Paternoster M. 2009. Gas hazard assessment at the Monticchio crater lakes of Mt. Vulture, a volcano in southern Italy. Terra Nova 21:83-7.

Carrias J-F, Amblard C, Bourdier G. 1998. Seasonal dynamics and vertical distribution of planktonic ciliates and their relationship to microbial food resources in the oligomesotrophic Lake Pavin. Archiv für Hydrobiologie 143:227-55.

Chapron E, Albéric P, Jézéquel D, Versteeg W, Bourdier J-L, Sitbon J. 2010. Multidisciplinary characterisation of sedimentary processes in a recent maar lake (Lake Pavin, French Massif Central) and implication for natural hazards. Natural Hazards and Earth System Sciences 10:1815-27.

Chapron E, Albéric P, Jézéquel D, Ledoux G, Massault M. 2012. Les archives sédimentaires de l'histoire du lac Pavin. In: Le Lac Pavin. Revue des Sciences Naturelles d'Auvergne 74-75:57-65.

De Benedetti AA, Funiciello R, Giordano G, Diano G, Caprilli E, Paterne M. 2008. Volcanology, history and myths of the Lake Albano maar (Colli Albani volcano, Italy). Journal of Volcanology and Geothermal Research 176:387-406.

Delibrias G, Guillier MT, Labeyrie J. 1972. Gif natural radiocarbon measurements VII. Radiocarbon 14(2): 280-320.

Fernandes R, Bergemann S, Hartz S, Grootes PM, Nadeau M-J, Melzner F, Rakowski A, Hüls M. 2012. Mussels with meat: bivalve tissue-shell radiocarbon age differences and archaeological implications. $R a$ diocarbon 54(3-4):953-65.

Fernandes R, Dreves A, Grootes PM, Nadeau MJ. 2013. A freshwater lake saga: carbon routing within the aquatic food web of Lake Schwerin. Radiocarbon, these proceedings, doi:10.2458/azu_js_rc.55.16357.

Geyh MA, Schotterer U, Grosjean M. 1998. Temporal changes of the ${ }^{14} \mathrm{C}$ reservoir effect in lakes. Radiocarbon 40(2):921-31.

Goslar T, Czernik J. 2000. Sample preparation in the Gliwice Radiocarbon Laboratory for AMS ${ }^{14} \mathrm{C}$ dating of sediments. Geochronometria 18:1-8.

Jézéquel D, Sarazin G, Prévot F, Viollier E, Groleau A, 


\section{$P$ Albéric et al.}

Michard G, Agrinier P, Albéric P, Binet S, Bergonzini L. 2012a. Bilan hydrique du lac Pavin. In: Le Lac Pavin. Revue des Sciences Naturelles d'Auvergne 74-75: 67-90.

Jézéquel D, Michard G, Viollier E, Prévot F, Groleau A, Sarazin G, Lopes F, Agrinier P, Albéric P, Bergonzini L. 2012b. Le cycle du carbone et les risques d'éruption gazeuse au Pavin. In: Le Lac Pavin. Revue des Sciences Naturelles d'Auvergne 74-75:91-110.

Juvigné E. 1992. Distribution of widespread late glacial and holocene tephra beds in the French Central Massif. Quaternary International 14:181-5.

Keaveney EM, Reimer PJ. 2012. Understanding the variability in freshwater radiocarbon reservoir offsets: a cautionary tale. Journal of Archaeological Science 39(5):1306-16.

Keaveney EM, Barry CD, Reamer PJ, Foy RH. 2012. ${ }^{14} \mathrm{C}$ as a tool to trace terrestrial carbon in a complex lake system: implications for food-web structure and carbon cycling. Poster presented at 21 st International Radiocarbon Conference 2012, Paris.

Lehours AC, Bardot C, Thenot A, Debroas D, Fonty G. 2005. Anaerobic microbial communities in Lake Pavin, a unique meromictic lake in France. Applied Environmental Microbiology 71:7389-400.

Levin I, Kromer B. 2004. The tropospheric ${ }^{14} \mathrm{CO}_{2}$ level in mid-latitudes of the Northern Hemisphere (19592003). Radiocarbon 46(3):1261-72.

Lopes F, Viollier E, Thiam A, Michard G, Abril G, Groleau A, Prévot F, Carrias J-F, Albéric P, Jézéquel D. 2011. Biogeochemical modelling of anaerobic vs. aerobic methane oxidation in a meromictic crater lake (Lake Pavin, France). Applied Geochemistry 26: 1919-32.

Louvat D. 1987. Géochimie isotopique du soufre et du carbone et circulation aquifères en roches cristallines de Suède centrale (STRIPA) et de Finlande. Thèse Université Paris-Sud.

Martin J-M, Meybeck M, Nijampurkar VN, Somayajulu BLK. 1992. ${ }^{210} \mathrm{~Pb},{ }^{226} \mathrm{Ra}$ and ${ }^{32} \mathrm{Si}$ in Pavin lake (Massif Central, France). Chemical Geology 94:73-181.

Maurin N, Amblard C, Bourdier G. 1997. Phytoplanktonic excretion and bacterial reassimilation in an oligomesotrophic lake: molecular weight fractionation. Journal of Plankton Research 19:1045-68.

Mayorga E, Aufdenkampe AK, Masiello CA, Krusche AV, Hedges JI, Quay PD, Richey JE, Brown TA. 2005. Young organic matter as a source of carbon dioxide outgassing from Amazonian rivers. Nature 436(7050):538-41.

McNichol AP, Aluwihare LI. 2007. The power of radiocarbon in biogeochemical studies of the marine carbon cycle: insights from studies of dissolved and particulate organic carbon (DOC and POC). Chemical Review 107:443-66.

Michard G, Viollier E, Jezequel D, Sarazin G. 1994. Geochemical study of a crater lake: the Lake Pavin, France - identification, location and quantification of chemical reactions in the lake. Chemical Geology 115: 103-15.

Moreira S, Boehrer B, Schultze M, Dietz S, Samper J. 2011. Modeling geochemically caused permanent stratification in Lake Waldsee (Germany). Aquatic Geochemistry 17:265-80.

Olsson IU. 2009. Radiocarbon dating history: early days, questions, and problems met. Radiocarbon 51(1):143.

Pazdur A, Fontugne MR, Goslar T, Pazdur MF. 1995. Late Glacial and Holocene water-level changes of the Gosciaz lake, central Poland, derived from carbon isotope studies of laminated sediment. Quaternary Science Reviews 14:125-35.

Reichert P. 1994. Aquasim - a tool for simulation and data analysis of aquatic systems. Water Science and Technology 30:21-30.

Reichert P. 1998. AQUASIM 2.0 Computer Program for the Identification and Simulation of Aquatic Systems. User Manual. EAWAG Report. ISBN 3-906484-19-5.

Schettler G, Schwab MJ, Stebich M. 2007. A 700-year record of climate change based on geochemical and palynological data from varved sediments (Lac Pavin, France). Chemical Geology 240:11-35.

Schwab MJ, Schettler G, Bruchmann C, Acksel D, Negendank JFW, Brauer A. 2009. Stratigraphy, chronology and paleoenvironment information of the sediment record from Lac Pavin, Massif Central (France). International Meeting-Lake Pavin and Other Meromictic Lakes, May 14-16, Besse et St Anastaise, France, Abstract. p 30.

Stebich M, Brüchmann C, Kulbe T, Negendank JFW. 2005. Vegetation history, human impact and climate change during the last 700 years recorded in annually laminated sediments of Lac Pavin, France. Review of Palaeobotany and Palynology 133:115-33.

Stuiver M. 1980. Workshop on ${ }^{14} \mathrm{C}$ data reporting. Radiocarbon 22(3):964-6.

Stuiver M, Polach HA. 1977. Discussion: reporting of ${ }^{14} \mathrm{C}$ data. Radiocarbon 19(3):355-63.

Thiam A. 2009. Biogéochimie du molybdène dans un lac de cratère: processus permanents et transitoires, contraintes isotopiques [PhD thesis]. Paris: Diderot University.

Viollier E, Albéric P, Jézéquel D, Michard G, Pèpe M, Sarazin G. 1995. Geochemical study of a crater lake: the Lake Pavin, France - trace element behaviour in the monimolimnion. Chemical Geology 125:161-72.

Zigah PK, Minor EC, Werne JP, McCallister SL. 2012a. An isotopic $\Delta^{14} \mathrm{C}, \delta^{13} \mathrm{C}$, and $\delta^{15} \mathrm{~N}$ investigation of the composition of particulate organic matter and zooplankton food sources in Lake Superior and across a size-gradient of aquatic systems. Biogeosciences 9(9): 3663-78.

Zigah PK, Minor EC, Werne JP. 2012b. Radiocarbon and stable-isotope geochemistry of organic and inorganic carbon in Lake Superior. Global Biogeochemical Cycles 26: GB1023, doi:10.1029/2011GB004132. 